\title{
Brazil, Ethiopia, and New Zealand lead the way on climate-smart agriculture
}

\author{
Christine Negra ${ }^{1 *}$, Sonja Vermeulen ${ }^{1}$, Luís Gustavo Barioni ${ }^{2}$, Tekalign Mamo ${ }^{3}$, Paul Melville $^{4}$ and Melaku Tadesse ${ }^{3}$
}

\begin{abstract}
As countries around the world face urgent agricultural challenges, the concept of 'climate-smart' agriculture (CSA) has been put forward to achieve climate change adaptation, mitigation, and food security synergistically. A new report explores how three countries are using integrated policy approaches to CSA and offers insights for how other countries can build CSA into their policy mix. Brazil has invested in research to support sustainable intensification while creating legal and enforcement mechanisms to protect forest areas as a response to unrestrained agricultural expansion driven by market demand. Ethiopia initiated innovative participatory watershed development programs, in partnership with numerous international institutions, which helped smallholder farmers to rehabilitate marginal land and break out of a poverty cycle. New Zealand has removed agricultural subsidies while partnering on research and development with the private sector as a way to ensure efficiency and resilience in an agricultural sector influenced by climate change and international trade dynamics. To assemble an integrated set of national policies that fosters CSA, governments will need context-specific assessments, strong multi-stakeholder institutions, coordination frameworks, and multi-scale information systems. Governments can select from an array of policy instruments ranging from regulatory mechanisms and economic incentives to public investments and educational campaigns. Many existing national policy goals and public programs designed to increase agricultural production, improve livelihoods, and reduce environmental risks can become important pillars of a national CSA strategy. Countries have obvious interests in fostering an agriculture sector that is climate-resilient, provides national needs for food, fiber, and fuel, and supports farm livelihoods. However, the incentives for national-level action toward reducing global greenhouse gas (GHG) levels are less clear in the absence of serious and shared international commitment. Integrated national CSA policies will be encouraged by clear, consistent signals from multilateral agencies, global donors, and international conventions and trade agreements that promote agriculture as a pathway for poverty reduction and food security.
\end{abstract}

Keywords: Climate-smart agriculture, Food security, Policy, Brazil, Ethiopia, New Zealand

\section{Commentary}

Background

Countries around the world are facing urgent agricultural challenges. The combination of a finite land base with growing populations and global consumption of food, fiber, and fuel is increasing competition among land uses. At the same time, unsustainable management practices and climate change, exacerbated by weak systems for information and governance, threaten land productivity [1]. In 2012, seven major strategies for addressing the interconnected challenges of food insecurity, unsustainable

\footnotetext{
* Correspondence: christine@ideapaths.org

${ }^{1}$ Independent consultant to CGIAR Research Program on Climate Change,

Agriculture and Food Security, Cali, Colombia

Full list of author information is available at the end of the article
}

agriculture, and climate change were proposed by the international scientific Commission on Sustainable Agriculture and Climate Change [2]. One of these strategies focused on integrating food security and sustainable agriculture into global and national policies.

The concept of 'climate-smart' agriculture is gaining greater visibility in international policy circles. Members of the recently launched Global Alliance for ClimateSmart Agriculture-including governments, multilateral agencies, farmers and other agricultural supply chain actors, researchers, and civil society-aspire to three transformational outcomes: (i) sustainable and equitable increases in agricultural productivity and incomes; (ii) greater resilience of food systems and farming livelihoods; and (iii) reduction and/or removal of greenhouse 
gas emissions associated with agriculture (including the relationship between agriculture and ecosystems), wherever possible ${ }^{\mathrm{a}}$. One of the leading strategies of this alliance is to promote the integration of climate-smart agriculture (CSA) into national policies. But what does it mean for CSA to become embedded in a country's policy framework? A wide variety of policy contexts means the approach will never be identical in any two countries, but there is great value in cross-country learning from case studies. This is the rationale for the report 'Integrated National Policy Approaches to Climate-Smart Agriculture: Insights from Brazil, Ethiopia, and New Zealand' recently published by the CGIAR program on Climate Change, Agriculture and Food Security [3]. The three countries were selected for their early action on CSA, in contrasting biophysical and socio-political environments (see Table 1). All three countries pursue agricultural development that centers on enhancing crop and livestock productivity rather than cropland, rangeland, or pasture expansion.

\section{Three country case studies}

In recent decades, Brazil has become a major player in international commodity markets and policy processes as well as a significant source of global greenhouse gas (GHG) emissions, primarily from agriculture and deforestation
[4-7]. A series of national policies have demonstrated a stewardship commitment for globally significant carbon and biodiversity reserves [7-10]. Catalyzed by a national pledge to the United Nations Framework Convention on Climate Change (UNFCCC) and numerous domestic legal and financial mechanisms, Brazil is pursuing a diverse set of climate change mitigation opportunities that emphasize sustainable agricultural intensification $[7,11,12]$. Brazil has built an impressive knowledge base on tropical agriculture and combined this with technology (e.g., monitoring and enforcement innovations) and policy (e.g., sectoral plans, financing, lending restrictions) to promote more sustainable, higher-yielding production practices [7]. Under Brazil's Low Carbon Agriculture (ABC) program, crop and livestock producers access low-interest loans to implement activities that align with national voluntary mitigation targets including low-till practices, nitrogen-fixation, and pasture rehabilitation [12]. Brazil's concurrent increase in total agricultural output and historically low rates of deforestation $[13,14]$ were aided by presidential leadership, an integrated forest conservation strategy that engaged 14 ministries and multiple stakeholders, support by global donors, and a mix of policy measures that included both restrictions (including new laws and enforcement of existing laws) and incentives [7].

Table 1 Biophysical and socio-political conditions of the three case study countries

\begin{tabular}{|c|c|c|c|}
\hline & Brazil & Ethiopia & New Zealand \\
\hline \multirow[t]{5}{*}{ Biophysical conditions } & - Land area: $8.5 \mathrm{M} \mathrm{km}^{2}$ & - Land area: $1.1 \mathrm{M} \mathrm{km}^{2}$ & - Land area: $0.3 \mathrm{M} \mathrm{km}^{2}$ \\
\hline & - Large biodiversity reserves & $\begin{array}{l}\text { - Highly diverse } \\
\text { agri-ecosystems }\end{array}$ & $\begin{array}{l}\text { - Geographically isolated island nation with } \\
\text { highly diverse climate zones }\end{array}$ \\
\hline & $\begin{array}{l}\text { - } 13.5 \% \text { of the world's potential } \\
\text { arable land }\end{array}$ & $\begin{array}{l}\text { - Land degradation } \\
\text { affects }>40 \mathrm{M} \text { ha }\end{array}$ & \\
\hline & $\begin{array}{l}\text { - Significant non-forested land } \\
\text { with agricultural potential }\end{array}$ & $\begin{array}{l}\text { - Annual soil erosion loss } \\
\text { of } \sim 1.9 \text { B tons }\end{array}$ & $\begin{array}{l}\text { - Of total land area, } 39 \% \text { is in pasture, } 1.6 \% \text { in } \\
\text { horticulture and cropping, and } 6.6 \% \text { in planted }\end{array}$ \\
\hline & & $\begin{array}{l}\text { - } 80 \% \text { of cultivated land } \\
\text { yields }<1 \text { ton/ha }\end{array}$ & production forest; 33\% is legally conserved \\
\hline \multirow[t]{4}{*}{ Socioeconomic conditions } & - Population: 203 M people & - Population: 88 M people & - Population: $~ 4.5$ M people \\
\hline & - GDP: 2.2 T USD & - GDP: $\sim 45$ B USD & - GDP: 180 B USD \\
\hline & - Major agri-commodity exporter & $\begin{array}{l}\text { Heavy economic } \\
\text { dependence on } \\
\text { agricultural exports }\end{array}$ & $\begin{array}{l}\text { - Heavy economic dependence on } \\
\text { agricultural exports }\end{array}$ \\
\hline & $\begin{array}{l}\text { - Population living on }<\$ 2 \\
\text { USD/day: } \sim 7 \%\end{array}$ & $\begin{array}{l}\text { Population living on }<\$ 2 \\
\text { USD/day: } \sim 70 \%\end{array}$ & - Population living on < \$2 USD/day: N/A \\
\hline \multirow[t]{3}{*}{ Climate change } & \multirow{2}{*}{$\begin{array}{l}\text { 3.2\% of total global GHG emissions } \\
\text { (2010); } 70 \% \text { of national GHG } \\
\text { emissions related to agriculture } \\
\text { and deforestation }\end{array}$} & $\begin{array}{l}\text { - }>40 \% \text { of national GHG } \\
\text { emissions related to } \\
\text { livestock }\end{array}$ & \multirow[t]{2}{*}{$\begin{array}{l}\text { 47\% of national GHG emissions related to } \\
\text { agriculture; agricultural emissions increased by } \\
15 \% \text { during 1990-2012 although emissions } \\
\text { intensity declined }\end{array}$} \\
\hline & & $\begin{array}{l}\text { High vulnerability of } \\
\text { rainfed agriculture to } \\
\text { climate change }\end{array}$ & \\
\hline & $\begin{array}{l}\text { - } 23 \% \text { of global forest carbon stored } \\
\text { in Amazon, which is threatened by } \\
\text { climate change }\end{array}$ & & $\begin{array}{l}\text { - Increasingly variable weather threatens } \\
\text { agriculture sector }\end{array}$ \\
\hline
\end{tabular}

These three countries differ dramatically in the size of their land bases, populations, economies, and farming systems; yet for all three, agriculture is a critical component of international trade, climate change mitigation potential, and national culture [5-7,15-19,31,37,38]. 
With high economic growth rates and the potential to be a major regional hydropower supplier, Ethiopia is already experiencing climate changes that threaten food security for millions of people. While Ethiopian agricultural production has consistently increased over the past decade, there is an urgent need to tackle low agricultural productivity, land degradation, and poverty while also reducing GHG emissions from a large livestock sector [15-18]. With the Climate-Resilient Green Economy (CRGE) Strategy, Ethiopia is marshaling national and international funds toward an integrated approach to low-carbon development anchored in sustainable agricultural intensification $[19,20]$. Processes for operationalizing the CRGE Strategy strongly emphasize a multi-scale 'whole of government' policy design [21]. As a global leader in testing and scaling up community-based development programs that link food security safety nets, land restoration, and enhancement of productive assets, Ethiopia has attracted support from global donors by developing tangible targets, staged implementation plans, and mechanisms to scale up [22-25]. Empowerment of women has resulted from a combination of policy shifts in land ownership and use rights, government-sponsored micro-lending, and nutrition and health education programs [26-28].

In New Zealand, an agriculture-dependent developed nation already experiencing significant economic impacts from climate change, the national policy mix demonstrates a commitment to minimizing agricultural subsidies [29] and maladaptive signals to agricultural producers. Under the Adverse Event Policy, producers are expected to adopt available risk management strategies, with support from government research and private sector advisory services, and are eligible for recovery assistance only if they undergo extreme and unpredictable circumstances. In the context of a national emissions trading scheme, New Zealand's agriculture sector is gaining experience with factor-based estimation of GHG emissions and receiving a stronger economic signal to afforest marginal agricultural land. Through a public-private initiative, carbon footprint assessments have been completed for over $80 \%$ of New Zealand agricultural exports, clarifying important sectoral emissions sources. Public-private research investments in sustainable agricultural intensification have achieved major improvements in emissions intensity, while supporting economic growth. New Zealand has used an iterative multi-stakeholder policy process to make fundamental policy shifts that have resulted in an agriculture system that is much better equipped to operate efficiently and to respond to climate change [30,31].

\section{Lessons for national CSA policy}

Policy interventions in Brazil, Ethiopia, and New Zealand illustrate the major technical and institutional investments that governments will need to make in pursuit of CSA.
National policy implementation of CSA is generally seen to include the following elements [32-34]:

\section{Context-specific assessments}

National policy makers can marshal domestic resources and international partnerships toward holistic assessments that enable stakeholders to gauge the potential for CSA pathways. Assessments should ideally cover both impacts of climate change on agriculture and capabilities and vulnerabilities within the sector. Robust estimates of costs and benefits (and beneficiaries) under current and climatesmart agriculture regimes can be complemented by assessment of barriers to scaling up CSA approaches (e.g., weak information or legal systems) and policy levers that can empower key social groups to take action (e.g., microlending to women; land tenure shifts).

For example, in Brazil, robust, multi-institutional engagement in preparation of National Communications to the UNFCCC and analysis published in international reports [35] pioneered methods for reporting and projecting land-based emissions, documented the significant contribution of land use to national GHG emissions, and catalyzed the eventual engagement of the agricultural sector in mitigation. In Ethiopia, the Rural Household Survey revealed the important contribution of both the 2003 community-level land registration policy and the 2000 reform of the Family Code to improved access for women to land and livestock [28]. In New Zealand, policy action on climate change was catalyzed by several modeling studies including a 2008 report that predicted greater drought frequency in pastoral systems [36] and a 2012 evaluation of adaptation options for all major production groups [37].

\section{Strong multi-stakeholder institutions}

Entrenched political positions among different stakeholder groups inhibit policy innovation necessary to accelerate CSA approaches. Stable platforms are needed through which political leaders, domestic constituencies, and international partners can explore shared risks and negotiate policy priorities. Transparent and credible informationsharing is a key function of multi-stakeholder institutional arrangements. As multi-stakeholder processes converge on policy objectives, governments can respond by developing natural resource governance mechanisms to incentivize action by farmers and other private sector actors.

For example, in 2000, the Brazilian Climate Change Forum, led by the President, was established to facilitate public, private, scientific, and civil society stakeholder engagement in climate change issues [12]. In 2009, the Ethiopian Strategic Investment Framework for Sustainable Land Management was launched to promote adoption of traditional and modern sustainable land management practices through multi-sectoral partnerships and harmonized investments [16,17]. In New Zealand, improvements in 
farm efficiency, including GHG emissions intensities, have been credited to removal of farm subsidies and R\&D investments. The lamb meat sub-sector, for instance, now produces slightly higher output from a 43\% smaller flock [31].

\section{Coordination frameworks}

Achieving tangible targets for adaptation, mitigation, and food security requires participation by government, producers, agribusinesses, and international partners. By establishing strategic frameworks, national governments can more effectively promote CSA by coordinating the contributions of private and civil sector actors including market incentives (e.g., market access), financial mechanisms (e.g., sustainability criteria for lending), technical assistance (e.g., producer support programs), and public campaigns. Coordinating agriculture, forestry, and land use policies-commonly under the mandate of different ministries-is important to avoid perverse outcomes. Multi-scale 'whole of government' models, with substantial powers at the local level, may be useful for designing and implementing new CSA-supportive policies while reducing maladaptive signals from existing land sector policies.

For example, in 2004, Brazil implemented the interministerial Action Plan for Prevention and Control of Legal Amazon Deforestation, which included 200 initiatives for planning, sustainable use, and monitoring of forested areas, supported by remote sensing and law enforcement for illegal logging $[7,9,10]$. In Ethiopia, the government built broad-based capacity for the CRGE Strategy through an inclusive design process, a high-level forum for reporting progress and addressing challenges, and diverse partnerships for technical implementation [19]. In New Zealand, under the Plan of Action for Sustainable Land Management and Climate Change, a variety of climate change initiatives for forestry, agriculture, horticulture, and arable farming sectors were undertaken in partnership with land managers, Mãori communities, and local government $[30,31,38]$.

\section{Multi-scale information systems}

Climate-smart agriculture entails high knowledge requirements for assessing risks, vulnerabilities, and contextspecific strategies for increasing agricultural productivity and reducing GHG emissions. To harvest the benefits of CSA, countries need inclusive knowledge systems including R\&D, advisory services (which should draw on knowledge generated in farmers' fields as well as in research centers), information technologies, and monitoring and evaluation. The ability to document and report on outcomes of improved methods and technologies is essential for producers to benefit from incentive programs (e.g., offset markets, subsidized credit), for 'late adopters' to be informed about potential benefits of CSA approaches and for voluntary and regulatory program managers to evaluate impact. Including farmers in information systems is critical. A partnership approach among government, land managers, and researchers can generate and share practical information for the agriculture sector including spatially explicit recommendations for combining tested methods and technologies for CSA. Financial and opportunity costs associated with testing and establishing CSA-supportive policies are likely to be more immediately apparent than CSA benefits, which may be distributed over time and space and accrue to new beneficiaries. Therefore, information systems are needed to estimate the full range of benefits and costs so that informed policy debates are possible.

Multi-scale information systems require significant investments and it is noteworthy that the governments of Brazil, New Zealand, and Ethiopia have all chosen to make these investments. For example, in Brazil, public sector agricultural $R \& D$ contributed to significant improvements in productivity and livelihoods as well as to reduced agricultural expansion rates [6]. In Ethiopia, to improve agricultural extension and smallholder productivity, the Ethiopian Soil Information System (EthioSIS) was initiated in 2011 and a National Soils Database and soil fertility map is being developed to determine soil nutrient deficiencies and develop tailored fertilization regimes [39]. Such information systems are designed to reach the local level, with a target of $70 \%$ of experts at district (woreda) level reporting use [17]. Sustained investment in extension services in recent years has been critical in raising mean cereal yields to 2.3 tons per hectare and enhancing women's knowledge on nutrition and health $[19,40]$. In New Zealand, sustainable dairy advisors work with farmers to assess risks and management options [31]. Building on domestic research investments from the private and public sectors, in 2009, New Zealand initiated the Global Research Alliance on Agricultural Greenhouse Gases (GRA), which now coordinates research on agricultural productivity and GHG emission reduction among more than 40 member countries $[30,41]$.

While the three case study countries illustrate progress toward an integrated, CSA-supportive national policy, they are also instructive regarding potentially circuitous pathways. In Brazil, the Forest Code has undergone significant changes since its origins in 1965 , notably the innovative 2001 requirement that $80 \%$ of original forest cover be retained on parcels in the Amazon region and the subsequent 2012 revision that pragmatically provided amnesty to noncompliant landowners (while also compelling participation in a rural environmental registry) $[12,42]$. In Ethiopia, of $3.6 \mathrm{M}$ ha of rural land targeted for agricultural development, only 470,000 ha have been leased, mostly to foreign investors for industrial 
crop production due to high capital requirements, and about 200,000 ha of leased land have been retaken by the government due to poor performance and noncompliance to the agreed modalities [43]. In New Zealand, the intention to include the farm sector within the obligatory emissions trading scheme is waiting on improvements in the cost-effectiveness of available agricultural emissions reduction technologies [31].

\section{Conclusions}

In the absence of clear international policy signals and strong global agreements, countries are making unilateral efforts to achieve the CSA 'triple win' of climate change adaptation, mitigation, and food security based on a pragmatic understanding of their unique economic, environmental, and institutional context. Brazil has invested in research to support sustainable agricultural intensification while creating legal, monitoring, and enforcement mechanisms to protect forest areas as a response to unrestrained agricultural expansion. Ethiopia partnered with international institutions to implement innovative food security and participatory watershed development programs to help smallholder farmers working on marginal land with limited technological resources to break out of a poverty cycle. New Zealand has removed agricultural subsidies while partnering on $R \& D$ with the private sector to embed emission efficiency and climate change adaptation in an agricultural sector threatened by climate change.

Together, these three country case studies demonstrate that to assemble an integrated set of national policies that fosters CSA, governments will need (a) context-specific assessments, (b) strong institutions, (c) coordination frameworks, and (d) multi-scale information systems. Many existing national policy goals and public programs designed to increase agricultural production, improve livelihoods, and reduce environmental risks can become important pillars of a national CSA strategy.

\section{Endnote}

${ }^{a}$ Joint Statement for Agriculture, Food Security and Nutrition at the Climate Summit 23 September 2014 (http://www.un.org/climatechange/summit/wp-content/ uploads/sites/2/2014/09/AGRICULTURE-Action-Plan.pdf).

\section{Abbreviations \\ CRGE: Climate-Resilient Green Economy; CSA: climate-smart agriculture; GHG: greenhouse gas; R\&D: research and development; UNFCCC: United Nations Framework Convention on Climate Change.}

\section{Competing interests}

The authors declare that they have no competing interests.

\section{Authors' contributions}

$\mathrm{CN}$ conceived of the study, led its design and coordination, and led the development of the manuscript. SV conceived of the study, participated in its design and coordination, and helped to draft the manuscript. LGB provided input and review of the Brazilian case study and edited the manuscript. TM and MT provided input and review for the Ethiopian case study and edited the manuscript. PM provided data and analysis used in the New Zealand case study and edited the manuscript. All authors read and approved the final manuscript.

\section{Acknowledgements}

The Ethiopian case study integrates information from a presentation given by Selam Abebe (formerly of the Environmental Protection Authority, Ethiopia) in October 2012 at a climate-smart agriculture workshop in Rome. Input for the New Zealand case study was provided by Todd Muller (Managing Director Co-operative Affairs, Fonterra), Emma Parsons (Global Sustainable Dairying Manager, Fonterra), and Lara Philips (Trader, Green Desk, Fonterra). The

CGIAR Research Program on Climate Change, Agriculture and Food Security (CCAFS) is a strategic partnership of CGIAR and Future Earth, led by the International Center for Tropical Agriculture (CIAT). The program is carried out with funding by CGIAR Fund Donors, the Danish International Development Agency (DANIDA), Australian Government Overseas Aid Program (AusAid), Irish Aid, Environment Canada, Ministry of Foreign Affairs for the Netherlands, Swiss Agency for Development and Cooperation (SDC), Instituto de Investigação Científica Tropical (IICT), UK Aid, Government of Russia, and the European Union (EU), with technical support from the International Fund for Agricultural Development (IFAD).

\section{Author details}

${ }^{1}$ Independent consultant to CGIAR Research Program on Climate Change, Agriculture and Food Security, Cali, Colombia. ${ }^{2}$ Brazilian Agricultural Research Corporation (Embrapa), Brasilia, Brazil. ${ }^{3}$ Ministry of Agriculture, Addis Ababa, Ethiopia. ${ }^{4}$ Ministry for Primary Industries, Wellington, New Zealand.

Received: 16 September 2014 Accepted: 21 November 2014 Published online: 15 December 2014

\section{References}

1. FAO-EPIC: Climate smart agriculture: capturing the synergies among mitigation, adaptation and food security in Malawi, Vietnam and Zambia. Project Brief. United Nations Food and Agriculture Organization, Economic and Policy Innovations for Climate-Smart Agriculture. 2013. Available at: http://www.fao.org/climatechange/epic/en/.

2. Beddington J, Asaduzzaman M, Clark M, Fernández A, Guillou M, Jahn M, Erda L, Mamo T, Negra C, Nobre CA, Scholes R, Sharma R, Van Bo N, Wakhungu J: The role for scientists in tackling food insecurity and climate change. Agriculture and Food Security 2012, 1:10.

3. Negra C: Integrated National Policy Approaches to Climate-Smart Agriculture. Insights from Brazil, Ethiopia, and New Zealand. CCAFS Report No. 11. Copenhagen: CGIAR Research Program on Climate Change, Agriculture and Food Security (CCAFS); 2014.

4. Barioni LG: Presentation: "Regional analysis of GHG mitigation through intensification of beef production: Emerging behaviors due to upscaling", March 22, 2013. California, USA: Davis; 2013.

5. Lambin EF, Meyfroidt P: Global land use change, economic globalization, and the looming land scarcity. Proceedings of the National Academies of Science 2011, 108(9):3465-3472.

6. Pereira PAA, Martha GB, Santana CAM, Alves E: The development of Brazilian agriculture: future technological challenges and opportunities. Agric Food Secur 2012, 1:4.

7. UNEP: The Emissions Gap Report 2012. Nairobi: United Nations Environment Programme (UNEP). 2012. Available at: http://www.unep.org/pdf/ 2012gapreport.pdf.

8. CPI: Deforestation Slowdown in the Legal Amazon: Prices or Policies? CPI Working Paper. Rio de Janeiro, Brazil: Climate Policy Initiative/PUC-Rio; 2012.

9. Evans K: How much credit can Brazil take for slowing Amazon deforestation and how low can it go? AlertNet:; 2013.

10. Portal Brasil: Action Plan for Protection and Control of Deforestation in the Amazon (PPCDAM). 12 May 2011. 2011. Available at: http://www.brasil.gov. br/meio-ambiente/2011/12/plano-de-acao-para-protecao-e-controle-dodesmatamento-na-amazonia-ppcdam.

11. Kissinger G: Corporate social responsibility and supply agreements in the agricultural sector: decreasing land and climate pressures. CCAFS Working Paper no. 14. Copenhagen: CGIAR Research Program on Climate Change, Agriculture and Food Security (CCAFS); 2012. Available at: www.ccafs.cgiar.org. 
12. La Rovere E, Poppe M: Brazil: Curbing forests emissions and anticipating energy issues. Challenges for climate policy and governance in key emerging countries Series, Working Papers N07/12. Paris, France: Institut du développement durable et des relations internationals, IDDRl; 2012:20.

13. Martha GB Jr, Alvesc E, Continia E: Land-saving approaches and beef production growth in Brazil. Agricultural Systems 2012, 110:173-177.

14. Barreto AGOP, Berndes G, Sparovek G, Wirsenius S: Agricultural intensification in Brazil and its effects on land-use patterns: an analysis of the 1975-2006 period. Global Change Biology 2013, 19(6):1804-1815.

15. Admassu H, Getinet M, Thomas TS, Waithaka M, Kyotalimye M: East African Agriculture and Climate Change: A Comprehensive Analysis - Ethiopia. Washington, DC: International Food Policy Research Institute; 2012.

16. FDRE: Ethiopian Strategic Investment Framework for Sustainable Land Management. Addis Ababa, Ethiopia: Federal Democratic Republic of Ethiopia, Ministry of Agriculture and Rural Development; 2008.

17. Tadesse M: Agriculture-Forest Linkages Towards a Landscape Approach: Experiences from the Sustainable Land Management Programme (SLMP), Ethiopia. Vietnam: presentation at the 2 nd Global conference on Agriculture, Food Security and Climate Change Hanoi; 2012. September 5, 2012. Available at: http://www.afcconference.com/images/3_7Sep/Docs/Tuesday/ WorkGroupB/Sess2/ethiopia-ccagric.fs.hanoivietnam.pp.pdf.

18. UNDP: Millennium Development Goals: About Ethiopia. New York: United Nations Development Programme (UNDP); 2012.

19. Abebe SK: Overview of Climate Resilient Green Economy Strategy of Ethiopia. Case study prepared for the "Learning from Experience and Early Interventions" workshop convened by the Meridian Institute in October 2012; 2012. Available at: http://merid.org/en/Content/Projects/

Climate_Change_and_Agriculture.aspx.

20. FDRE: Ethiopia's Climate Resilient Green Economy (CRGE) Strategy. Addis Ababa: Federal Democratic Republic of Ethiopia; 2011.

21. UNDESA: A guidebook to the Green Economy, Issue 3: exploring green economy policies and international experience with national strategies. New York, USA: United Nations Department of Economic and Social Affairs, Division for Sustainable Development; 2012. Available at: http://sustainabledevelopment. un.org/content/documents/738GE\%20Publication.pdf.

22. Dieng A: CSA and Green Growth: Experiences from the Horn of Africa" presentation at the 2nd Global conference on Agriculture. In Food Security and Climate Change Hanoi, Vietnam. 2012. Available at: http://www.afcconference.com/images/3_7Sep/Docs/Tuesday/WorkGroupB/ presentationcsahanoiwfpdiengfinal-abdoudieng.pdf.

23. HLPE: Social Protection for Food Security. Rome: A report by the High Level Panel of Experts on Food Security and Nutrition of the Committee on World Food Security; 2012.

24. World Bank: Productive Safety Net Project (PSNP). The World Bank. 2011. Available at: http://web.worldbank.org/WBSITE/EXTERNAL/COUNTRIES/ AFRICAEXT/0 "contentMDK:21072837 menuPK:1804110 pagePK:146736 piPK:146830 theSitePK:258644,00.html.

25. WFP: MERET: Land Regeneration in Ethiopia. World Food Programme; 2012. Available at: http://www.wfp.org/disaster-risk-reduction/meret.

26. Gebeyehu ZH: Towards Improved Transactions of Land Use Rights in Ethiopia. Paper presented at the Annual World Bank Conference on Land and Poverty. Washington, DC: The World Bank; 2013.

27. Hosaena G: Links between Tenure Security and Food Security: Evidence from Ethiopia. Paper presented at the Annual World Bank Conference on Land and Poverty. The World Bank: Washington, DC; 2013.

28. KN Q: Policy Reform toward Gender Equality in Ethiopia: Little by Little the Egg Begins to Walk. IFPRI Discussion Paper 01226; 2012. Available at: http://www. ifpri.org/sites/default/files/publications/ifpridp01226.pdf.

29. OECD: Producer and Consumer Support Estimates database, 1986-2010. Paris: The Organisation for Economic Co-operation and Development; 2010. Available at: http://www.oecd.org/tad/agriculturalpoliciesandsupport/ producerandconsumersupportestimatesdatabase1986-2010.htm.

30. Dale A: Presentation: "Towards Sustainable Agriculture: the OECD Green Growth Strategy" at the 2nd Global Conference on Agriculture, Food Security and Climate Change. Hanoi, Vietnam: 2012. Available at: http://www.afcconference.com/ images/3_7Sep/Docs/Tuesday/andrew_tuesday_9-10amfinal_sans.pdf.

31. Hayden M: Presentation: Climate Change Mitigation and Adaptation in New Zealand" at a workshop on Agriculture and Climate Change: Learning from Experience and Early Interventions. Rome, Italy: 2012. Available at: http://climate-agriculture.org/New_Zealand.aspx.
32. FAO: 'Climate-Smart' Agriculture: Policies, Practices and Financing for Food Security, Adaptation, and Mitigation. Rome: United Nations Food and Agriculture Organization; 2012.

33. FAO: Developing a Climate-Smart Agriculture Strategy at the Country Level: Lessons from Recent Experience. Background Paper for the Second Global Conference on Agriculture, Food Security and Climate Change, Hanoi, Vietnam, 3-7 September 2012. Rome: United Nations Food and Agriculture Organization; 2012.

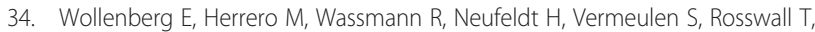
Campbell B, Hellin J, Jarvis A, Challinor A, Snook L, Smakhtin V, Kinyangi J: Setting the agenda: Climate change adaptation and mitigation for food systems in the developing world. CCAFS Working Paper no. 29. Copenhagen: CGIAR Research Program on Climate Change, Agriculture and Food Security (CCAFS); 2012. Available at: www.ccafs.cgiar.org.

35. de Gouvello C, Soares Filho BS, Nassar A, Schaeffer R, Alves FJ, Alves JWS: Brazil Low-carbon Country Case Study. Washington, DC: The World Bank Group; 2010.

36. Wratt D, Mullan B, Tait A, Woods R, Baisden T, Giltrap D, Lock K, Hendy J, Kerr S, Stroombergen A, Stojanovik A: Costs and benefits of climate change and adaptation to climate change in New Zealand agriculture: what do we know so far? Contract report by EcoClimate Consortium: Integrated Research on the Economics of Climate Change Impacts Adaptation and Mitigation. Wellington: Ministry of Agriculture and Forestry; 2008.

37. Clark AJ, Nottage RAC, Wilcocks L, Lee JM, Burke C, Kalaugher E, Roche J, Beukes P, Lieffering M, Newton PCD, Li FY, Vibart R, Teixeira El, Brown HE, Fletcher AL, Hernandez-Ramirez G, Soltani A, Viljanen-Rollinson S, Horrocks A, Johnstone P, Clothier B, Hall A, Green S, Dunningham A, Kirschbaum MUF, Meason D, Payn T, Collins DBG, Woods RA, Rouse H, et al: Impacts of climate change on land-based sectors and adaptation options. In Stakeholder Report to the Sustainable Land Management and Climate Change Adaptation Technical Working Group. Edited by Clark AJ, Nottage RAC, Hansford D. Wellington: Ministry for Primary Industries; 2012:76.

38. New Zealand Government: New Zealand's Climate Change Solutions: Sustainable Land Management and Climate Change, a Plan of Action. Wellington, NZ: Ministry of Agriculture and Forestry; 2007. Available at: http://maxa.maf.govt.nz/climatechange/slm/poa/maf-plan-of-action.pdf.

39. ATA: Ethiopian Soil Information System (EthioSIS). Addis Ababa: Ethiopian Agricultural Transformation Agency (ATA); 2012.

40. ATA: Annual Report: Transforming Agriculture in Ethiopia. Addis Ababa: Ethiopian Agricultural Transformation Agency (ATA); 2014

41. GRA. 2011. Global Research Alliance website. www.globalresearchalliance.org

42. Nepstad D, McGrath D, Stickler C, Alencar A, Azevedo A, Swette B, Bezerra T, DiGiano M, Shimada J, da Motta RS, Armijo E, Castello L, Brando P, Hansen MC, McGrath-Horn M, Carvalho O, Hess L: Slowing Amazon deforestation through public policy and interventions in beef and soy supply chains. Science 2014, 344:1118-1123.

43. Baumgartner P: Impact of large-scale land investments on income, prices and employment: empirical analyses in Ethiopia. Paper presented at the Annual World Bank Conference on Land and Poverty. Washington, DC: The World Bank; 2013.

\section{Submit your next manuscript to BioMed Central and take full advantage of:}

- Convenient online submission

- Thorough peer review

- No space constraints or color figure charges

- Immediate publication on acceptance

- Inclusion in PubMed, CAS, Scopus and Google Scholar

- Research which is freely available for redistribution 